\title{
Holocene fluvial response to climate change and human activities; Burgundy, France.
}

\author{
E.C. Straffin ${ }^{1} \&$ M.D. Blum ${ }^{2}$ \\ 1 Corresponding author; Department of Geosciences, Edinboro University of \\ Pennsylvania, Edinboro, PA 16444 USA \\ 2 Department of Geosciences, University of Nebraska, Lincoln, NE 68588 USA
}

Manuscript received: January 2001; accepted: February 2002

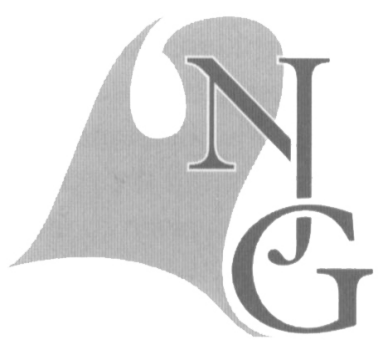

\begin{abstract}
Alluvial deposits of the Loire/Arroux trunk/tributary system record distinct, synchronous episodes of regional fluvial adjustment. Changes in facies and depositional style through time can be interpreted with a modern analogue model that relates vegetative cover/human influence with sediment supply, and modes of atmospheric circulation with the paths and styles of storms that drive variable discharge regimes across western Europe.

Zonal atmospheric circulation results in a Mediterranean style climate over southern Burgundy, producing dry conditions punctuated by infrequent, large floods. Episodic overbank sedimentation and the burial of thin paleosols in sandy overbank facies is indicative of this style of fluvial activity, ca 1300 years BP. Humans may have increased the available volume of fine grained sediment at this times through increased agricultural activity along valley axes, however facies match that expected from a 'flashy' discharge regime.

In contrast, meridional circulation patterns result in a maritime style climate over southern Burgundy, with the intrusion of storms, moist conditions and frequent, moderate magnitude discharges. Wide, deep channels, thick channel facies and thin overbank facies are indicative of this style of fluvial activity, recorded in deposits dating to ca 4050 to 3200 years BP. Strong meridional conditions and extreme climatic variability during the Little Ice Age resulted in very large discharges that straightened and widened channels, while scouring and obscuring older terraces (ca 500 years BP). Deposition over the last two centuries is related to increasingly zonal circulation and infrequent, large (over-bank) floods. Changes in fluvial dynamics over the last 300 years can be attributed primarily to climatic control, as there has been very little change in land-use over that period.
\end{abstract}

Keywords: climate, fluvial, France, Holocene, Loire

\section{Introduction}

The alluvial landscape holds the potential for developing a detailed record of landscape response to environmental change and human activities over a wide range of temporal and spatial scales (e.g. Antoine, 1994, 1997; Blum \& Tornqvist, 2000; Blum \& Straffin, 2001; Bridgland, 2000; Kozarski et al., 1988; Schirmer, 1988; Starkel, 1991a; Vandenberghe, 1995). Most often, reconstructed ancient alluvial landscapes have been compared with empirical proxy records of environmental change (e.g. pollen and lake levels records from continental interiors, and oxygen isotopes from ice and marine cores), in order to develop models and test hypotheses concerning the impacts of climate and human activities on fluvial systems (e.g. Fuller et al., 1998; Straffin et al., 1999). However, there has been less discussion concerning the details of floodplain sedimentation patterns and corresponding relationships to changing flood magnitude and frequency, brought about by those climate changes (e.g. Benito et al., 1996; Brown, 1998). The 
impact of changing climate/flood regime on fluvial systems should be recorded in floodplain stratigraphy (Brackenridge, 1988) and this information can be used in conjunction with the proxy record to better interpret paleohydrologic conditions, and to compare/contrast climatic and anthropogenic effects on fluvial systems (e.g. Brown, 1998; Rumsby \& Macklin, 1996).

By documenting the recent record of atmospheric, hydrologic, and land use change, region-specific models of fluvial response to these factors can be developed, and used to interpret that regions alluvial stratigraphic framework (e.g. Macklin \& Lewin, 1993). To develop a historic analogue model for fluvial response to climate change and human activities, it is necessary to examine the dependent relationships between channel morphology/facies, discharge, and texture and quantity of alluvial sediments for the basin under study (Knox, 1983; Schumm \& Brackenridge, 1987). In anthropogenically-unmodified catchments over short intervals of time $\left(10^{2}\right.$ to $10^{3}$ years), climate is the dominant control on discharge regime and sediment yield, both directly through variation in precipitation duration and intensity, and indirectly through climatic controls on vegetation, which in turn affects rates and amounts of runoff and sediment yield (Langbein \& Schumm, 1958; Ohmori, 1983). However, the pervasive overprint of human activities during the last 5-3 ky in western Europe makes gen- eralizations concerning fluvial response to climate change difficult (Starkel, 1987; 1991a) as the degree to which humans have impacted the landscape is often unknown. A historic analogue model that relates fluvial response to changes in flood magnitude and frequency as a function of climatic variability, and changes in sediment yield as a function of land-cover, is possible where those records exist.

The upper Loire River and a major tributary, the Arroux River, are well suited to this type of study due to location between contrasting climatic regimes (Fig. 1; Crumley, 1993; Staron, 1990), well documented changes in land-use and anthropogenic activities (Berry, 1987; Crumley \& Marquardt, 1987), strong correlations between regional and global proxy records (e.g. Fauquette et al., 1999; Reille \& De Beaulieu, 1988; Rousseau et al., 1993; Siffendine et al., 1996; Tzedakis et al., 1997), and a readily studied alluvial succession (Straffin et al., 1999). The Loire/ Arroux system is also relatively large (Table 1), and should be less affected by localized and internal complex-response mechanisms (e.g. Blum et al., 1994).

\section{Factors Driving Fluvial Change}

\section{Discharge regimes and atmospheric circulation}

Significant spatial coherence and cyclical changes of precipitation have been documented across western

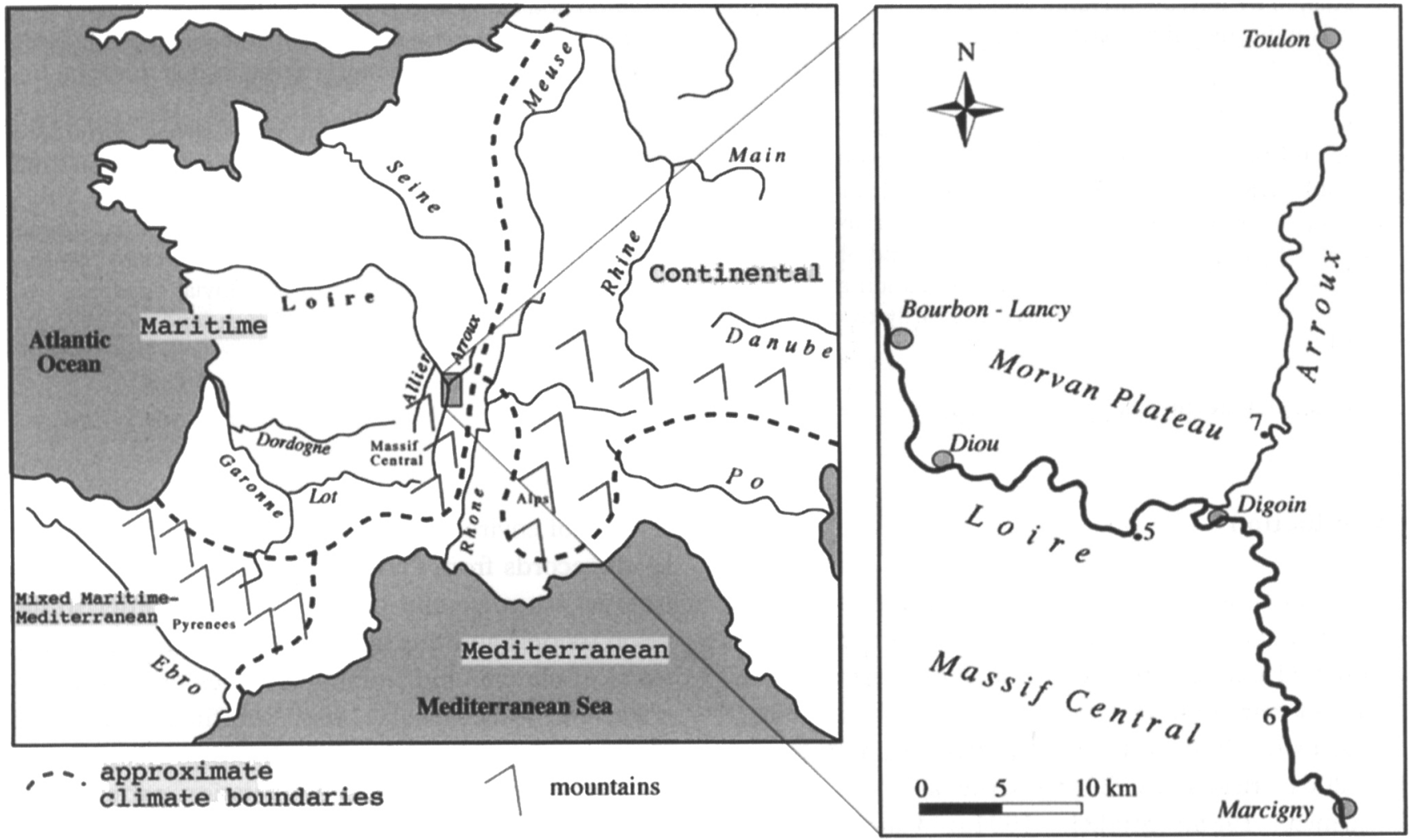

Fig. 1. Map illustrating location of major physiographic features and approximate climatic boundaries. Inset shows detail of the Loire and Arroux Rivers and larger villages within the study area. Numbers show location of photographs used in other Figs. 
Table 1. Drainage basin and discharge characteristics of the Loire and Arroux Rivers (from DIREN, 1996).

\begin{tabular}{lcr}
\hline & Arroux & Loire \\
\hline drainage basin area $\left(\mathrm{km}^{2}\right)$ & 3166 & 9315 \\
maximum discharge $\left(\mathrm{m}^{3} / \mathrm{s}\right)$ & 429 & 1350 \\
minimum discharge $\left(\mathrm{m}^{3} / \mathrm{s}\right)$ & 0.8 & 2 \\
Average annual discharge $\left(\mathrm{m}^{3} / \mathrm{s}\right)$ & 35 & 94 \\
\hline
\end{tabular}

Europe over the period of historical monitoring (e.g. Goossens, 1985; Tabony, 1981; Vines, 1985; Pandzic \& Trninic, 1992). More recently, the spatial distribution of precipitation has been related to the paths of storms, that are controlled by atmospheric pressure patterns over the Atlantic ocean (Dai et al., 1997; Hurrell \& Van Loon, 1997; Rodwell et al., 1999; Rogers, 1997). Fluctuations in discharge regimes of European rivers during the historic period (last 100 years) also show a definite spatial structure to discharge variation (Gustard et al., 1989; Probst \& Tardy, 1987; Probst, 1989). The most common pattern was one where all rivers were either above or below average values. At other times, however, discharge regimes of western European rivers (Rhône, Loire, Garonne, Seine, and Rhine) contrast significantly with discharge regimes of southern European rivers (Ebro and Po Rivers) (Probst, 1989). Aubert (1995) showed that the upper Loire and the Arroux Rivers generally matched the annual discharge fluctuations observed in other western European rivers, as identified by Probst (1989) and Probst \& Tardy (1987). In fact, a comparison of Rhône, Garonne, and Loire River discharges shows a significant correspondence in the timing of events in the annual maximum series (Fig. 2), again suggesting a strong spatial coherence in discharge regimes for major rivers.

Regional variations in climate and corresponding hydrological regimes, driven by atmospheric and oceanographic circulation patterns in the Atlantic Ocean (Leroux, 1990), define the maritime-, Mediterranean-, and continental-style climates that influence western Europe (Staron, 1990; Fig. 1). The southern Burgundy region lies near the boundary between these zones, and shifts in the position and increased dominance of climatic zones should cause correlative changes in fluvial discharge regimes through time. For example, as hemispheric temperatures increase, the atmospheric pressure gradient increases as well, causing increased zonal flow and the displacement of storm tracks to more northern latitudes (Hurrell, 1995; Hurrell \& Van Loon, 1997). Primary storm activity during these episodes occur during the early winter, when unstable, southeasterly storms produce infrequent, large magnitude floods in the Massif Central uplands (Blanchet, 1990; Staron, 1993), typical of a Mediteranean style climate.

The magnitude-frequency characteristics of maximum annual discharges for the entire Loire River basin (area 115,000 $\mathrm{km}^{2}$ ) is illustrated in Fig. 3, following the example of Knox (1983). Although well downstream from the study area, the length of the discharge record at Montjean (115 years) provides a means by which to establish relationships between flood magnitude - frequency, and atmospheric circulation. The time series is divided into periods of zonal versus meridional atmospheric conditions, defined by Hurrell \& Van Loon (1997), and closely corresponding with the periods identified by Lamb (1984a) and Knox (1983). The average of discharges with exceedence probabilities (EP; inverse of recurrence interval) of $5 \%$ and $2 \%$ vary markedly between zonal and meridional episodes. The largest (least frequent) discharges (e.g. $2 \% \mathrm{EP}$ ) on record occurred during a period of zonal circulation. Higher frequency discharges (e.g. 5\% EP) during zonal episodes are of smaller magnitude than those during meridional circulation. Total discharge variability is also greatest during zonal conditions (Fig. 3).

Increased meridionality, mixing of airmasses, increased storminess, and climatic variability follow periods of cooling (Harman, 1991). Climatic instability during cool episodes, such as the Little Ice Age and within the period of instrumental monitoring, for example, have been attributed to more meridional circulation (Moses et al., 1987; Lamb, 1982; 1984a,b). These conditions cause the paths of large storms to move into southern parts of Europe (Hurrell, 1995; Hurrell and van Loon, 1997), causing frequent winter precipitation and generally high humidity characteristic of maritime style climates. Discharges are generally large for most flood frequencies during periods of meridional circulation, with less variation in flood magnitudes than that found during periods of zonal circulation (Fig. 3).

Cool, dry air from the northeast is responsible for severe summer droughts and abnormally cold winters, characteristic of continental-style climates to the north and east of Burgundy (Fager \& Lozek, 1982). Either meridional or zonal flows can create atmospheric blocking, and the resulting dominance of high pressure over the continental interior, producing few storms and dry conditions in southern Burgundy.

\section{Land-use and changes in sediment supply}

In addition to discharge regime, sediment supply is fundamental in shaping the morphology of fluvial channels (e.g. Knox, 1983; Schumm \& Brackenridge, 1987). Over short temporal spans $\left(10^{2}\right.$ years $)$, sedi- 

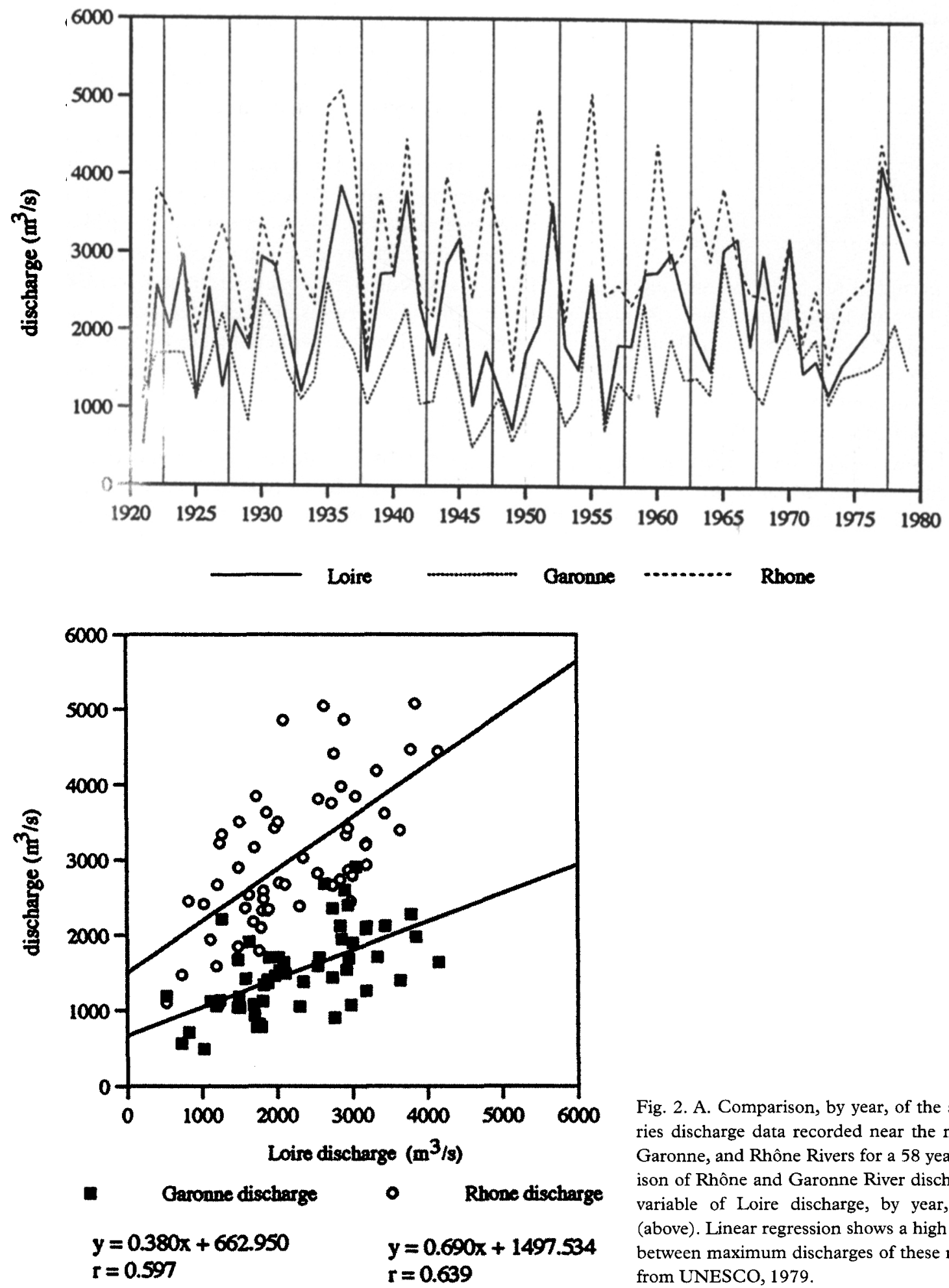

Fig. 2. A. Comparison, by year, of the annual maximum series discharge data recorded near the mouths' of the Loire, Garonne, and Rhône Rivers for a 58 year record. B. Comparison of Rhône and Garonne River discharges as a dependent variable of Loire discharge, by year, for the same time (above). Linear regression shows a high correlation ( $r$ values) between maximum discharges of these rivers. Discharge data from UNESCO, 1979.

ment supply is most strongly conditioned at regional scales by climate and anthropogenic influences, through control on vegetative cover and availability of sediment (Langbein \& Schumm, 1958; Ohmori, 1983). Sediment availability in the Loire Basin has probably not been severely limited over the last $\mathbf{1 5 0}$ $\mathrm{ky}$, due to the wide-spread occurrence of unconsolidated Plio-Pleistocene fluvial and lacustrine deposits that line the channel through much of this reach. Sed- iment supply thus has been controlled primarily by the effects of vegetation and human influence on landscape stability. This relationship is illustrated for the Loire and Arroux basins by Aubert (1995) who distinguished two distinct regions of sediment yield variation. In the upper Arroux basin, low sediment concentrations were recorded for areas dominated by arboreal vegetation. In the lower Arroux and the Loire valleys, the landscape is more actively cultivated 


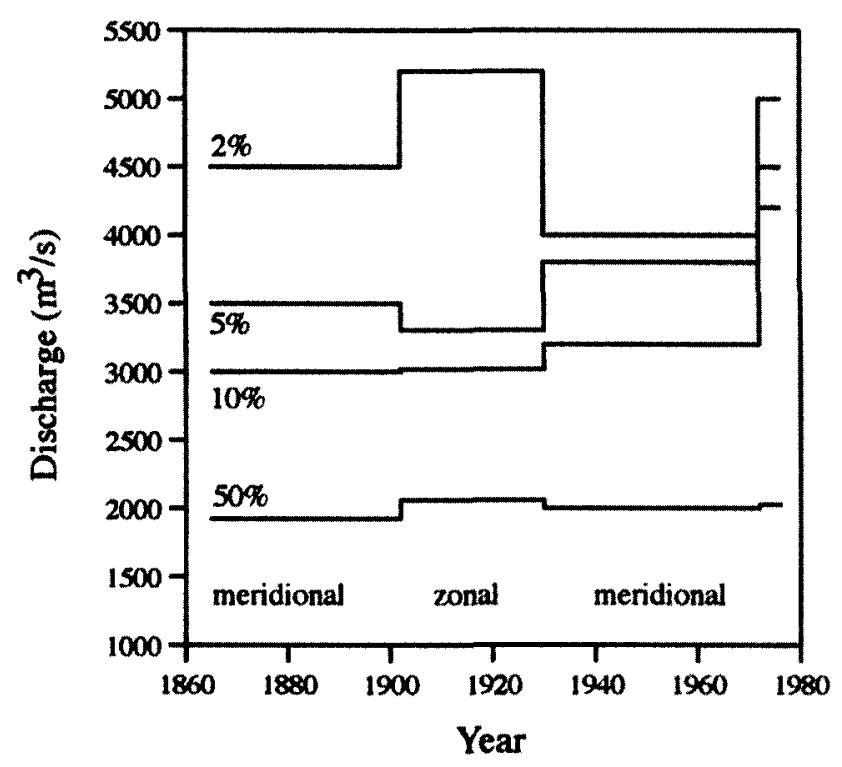

Fig. 3. A time series illustrating the average magnitude of floods with different exceedance probabilities (EP; inverse of recurrence interval) during periods of meridional and zonal circulation, as defined by Hurell \& van Loon (1997). Annual maximum series discharge data for the Loire River at Montjean $\left(115,000 \mathrm{~km}^{2}\right)$ taken from UNESCO, 1979.

and sediment yields are greater than in upland forested regions. Sediment concentrations also correlate to discharge, with maximum sediment yields occurring during winter, corresponding with maximum discharge and discharge variability. Variation in land-use patterns and vegetation through time should thus alter sediment yield in a predictable fashion (e.g. Knox, 1975), with increased sediment yield during periods of increased cultivation, grazing and clearing, and during periods of increased discharge variability (Mediterranean style climates). Decreased sediment yields should occur during periods of reforestation, decreased cultivation, and lower discharge variability (maritime style climates).

Berry (1987) describes the impact of people in the southern Burgundy landscape, who first significantly affected regional land-use patterns in this area during the Iron Age, with mixed agrarian/industrial communities centered in upland settings. Land-use in the Arroux valley during the Iron Age included mining of iron, tin, copper, and coal. Deforestation of the upper Arroux basin began in the Late Iron Age, proceeded through the Roman period, and is attributed to the need to fuel iron smelters in the region (Crumley \& Marquardt, 1987). These activities would have increased sediment yield from hillslopes for the first time since the Neolithic, but the geomorphic impact of these events is not widespread (Crumley, 1987). The Loire River immediately upstream from the confluence with the Arroux lacks these mineral resources, and was probably less affected by mining activity than the smaller Arroux valley.

Following the Iron Age, Roman land use practices were introduced, including monocropping of valley bottoms, marking a definite trend away from earlier upland agro-pastoral practices. The shift from upland to lowland settings and increased cultivation of valley bottoms has been related to an increasingly Mediterranean style climate (Crumley \& Marquardt, 1987; Gunn \& Crumley, 1991), that may have fostered those changes in land use. This shift in the focus of agricultural activities would have increased the potential for soil loss from valley bottoms, but reduced sediment yield from upland settings. Following the Roman period, civil upheaval in the seventh, ninth, and tenth centuries resulted in re-occupation of fortified hilltops, thus again shifting intensive land-use (and altering sediment yields) between upland and valley settings (Berry, 1987).

The Cassinni maps of 1759 document the final vestiges of the post-Medieval landscape and provide an early cartographic record for southern Burgundy. Early geologic maps (ca 1848-1897), World War II and modern aerial photography also provide information concerning topography, channel position, and morphology. From comparison of maps and photographs, it is apparent that development in larger urban areas has progressed rapidly, but smaller villages like those in the rural setting of southern Burgundy have not experienced regionally significant change in land-use practices over the last 300 years. This marked lack of landscape change is further evidenced by the persistence of multi-generational family landownership, and the endurance of farms, hedgerows and upland roads, many of which date back 2000 years (Hargrove, 1994; Jones, 1994).

\section{Holocene stratigraphy of the Loire/Arroux system}

\section{Overview}

Alluvial terraces and associated underlying deposits along $60 \mathrm{~km}$ of the Loire-Arroux system have been differentiated and mapped, providing a record of the preserved middle Pleistocene-Holocene alluvial history (Fig. 4). Units were initially differentiated on the basis of surface morphology, as expressed on aerial photographs. Large quarries and natural cut-banks provided excellent three-dimensional exposure of deposits, revealing buried units and complexities not readily apparent from surface morphology alone. Facies and bounding unconformities (soils and erosional surfaces) were described following the terminology of 

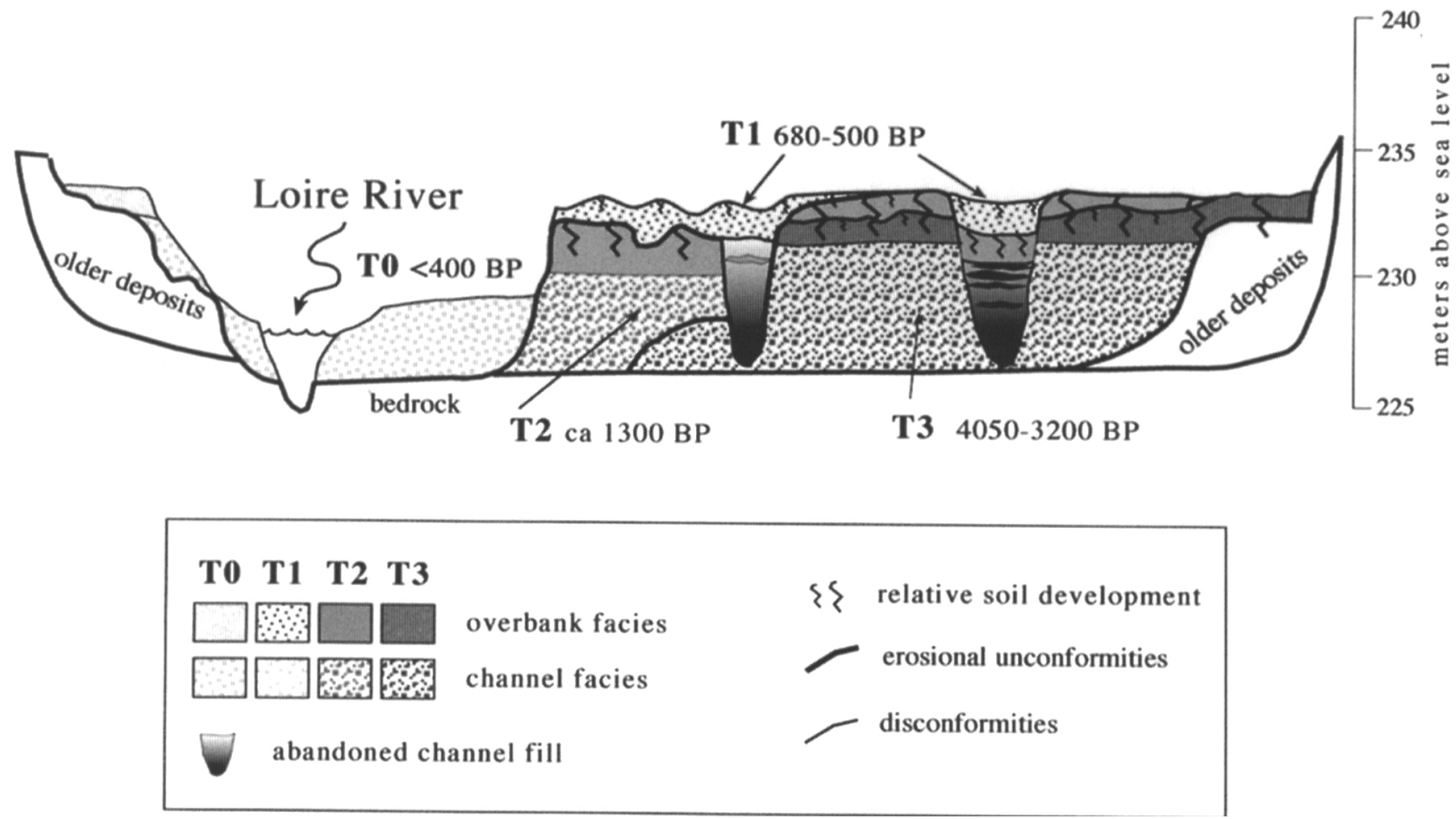

Fig. 4. Schematic valley cross section summarizing geometry and facies architecture of Holocene depositonal units in the Loire and Arroux valleys. No horizontal scale, but maximum Holocene floodplain width is approximately $3 \mathrm{~km}$.

Miall (1996) and Birkeland (1984) from more than 20 sites throughout both valleys (Straffin, 2000). Optically stimulated luminescence (OSL) ages, calibrated radiocarbon ages (Table 2), historical data (maps and photographs), and temporally-diagnostic artifacts constrain the age of depositional units (Colls, 1999; Colls et al., 2001; Straffin et al., 1999). Three major
Holocene terraces (T3, T2, and T1) have been identified (Fig. 4).

\section{Unit T3}

Where preserved, the T3 surface is $4-5 \mathrm{~m}$ above the modern low-water channel, and displays a well-de-

Table 2. Comparison of OSL and radiocarbon ages with depositional units. OSL ages from University of Oxford (UK) (after Colls et al., 2000). Radiocarbon ages from University of Texas-Austin Radiocarbon Laboratory (USA). Radiocarbon years are calibrated to calendar years using CALIB (Stuiver et al., 1998).

osL

\begin{tabular}{lclclrr}
\hline Lab & $\begin{array}{l}\text { Grain size } \\
(\mu \mathbf{m})\end{array}$ & $\begin{array}{l}\text { Dose rate } \\
(\mathbf{G y} / \mathbf{k a})\end{array}$ & $\begin{array}{l}\text { Age yrs BP } \\
+/ \text { - error }\end{array}$ & River & Unit & Material \\
\hline SOG1026/2 & $90-125$ & $6.1+/-0.16$ & $500+/-40$ & Loire & T1 & Overbank sand \\
SOG 1021/1 & $90-125$ & $8.25+/-0.20$ & $680+/-40$ & Loire & $\begin{array}{l}\text { T1 } \\
\text { T3 }\end{array}$ & $\begin{array}{l}\text { Overbank sand } \\
\text { Point bar sand }\end{array}$ \\
\hline
\end{tabular}

\section{RADIOCARBON}

\begin{tabular}{|c|c|c|c|c|c|c|}
\hline Lab & $\begin{array}{l}\text { Uncorrected Age } \\
\text { (yrs BP } \\
+/ \text { - error) }\end{array}$ & $\begin{array}{l}\text { Corrected Age } \\
\text { (yrs BP) }\end{array}$ & $\begin{array}{l}\text { Calibrated Age* } \\
\text { (yrs BP) }\end{array}$ & River & Unit & Material \\
\hline Tx8569 & $500+/-50$ & 440 & 524 & Arroux & $\mathrm{T} 1$ & wood \\
\hline $\mathrm{T} \times 8571$ & $1270+/-40$ & 1260 & 1204 & Loire & $\mathrm{T} 2$ & wood \\
\hline $\mathrm{Tx} 8572$ & $1420+/-60$ & 1420 & 1307 & Arroux & $\mathrm{T} 2$ & wood \\
\hline $\mathrm{Tx} 8568$ & $2990+/-40$ & 2930 & 3184 & Loire & $\mathrm{T} 3$ & wood \\
\hline $\mathrm{Tx} 8240$ & $3040+/-50$ & 3010 & 3312 & Loire & $\mathrm{T} 3$ & wood \\
\hline $\mathrm{Tx} 8574$ & $3290+/-50$ & 3300 & 3541 & Loire & $\mathrm{T} 3$ & wood \\
\hline $\mathrm{Tx} 8573$ & $3680+/-60$ & 3680 & 4050 & Loire & $\mathrm{T} 3$ & wood \\
\hline
\end{tabular}




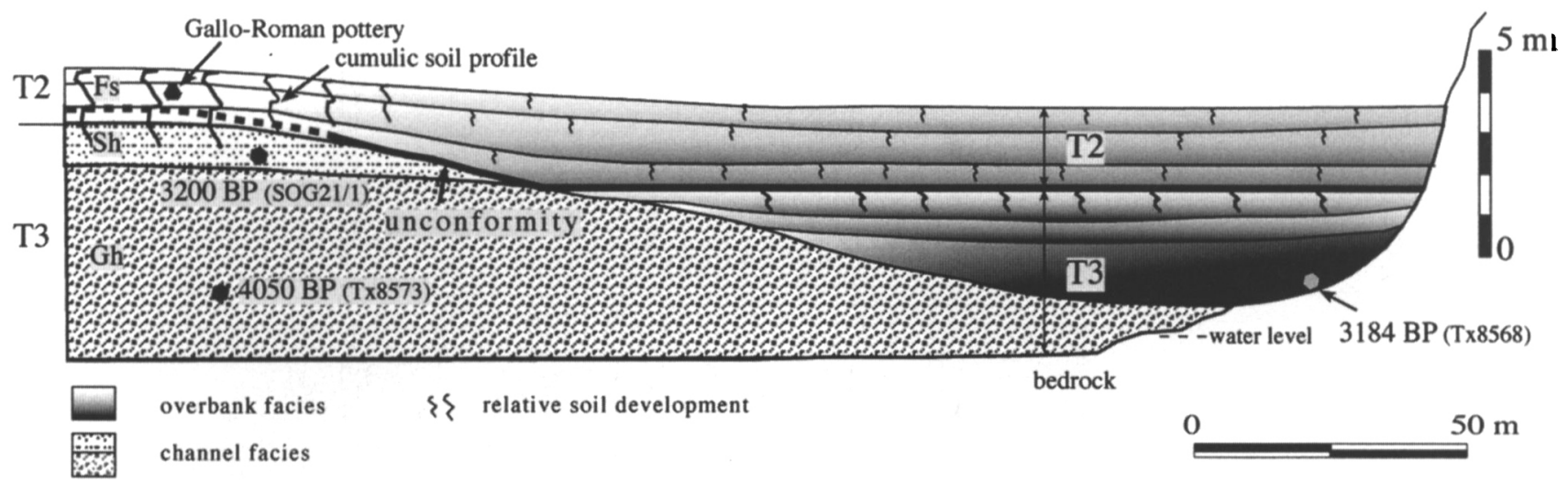

Fig. 5. Cross sectional sketch of unit T3 buried below T2, from a long cut bank exposure along the Loire River. Scale controlled by measured sections. T3 deposits are predominantly thick gravel facies with minor overbank facies, and thin, organic rich silt in an abandoned channel fill. $\mathrm{T} 2$ consists of a series of silty overbank deposits. In low-lying landscape positions, silts are separated by weak paleosols. In topographically high positions, paleosols and silt merge into cumulic soil profiles.

fined meandering channel morphology. Exposures along cutbanks and quarries show that T3 channel facies consist of single-story ( $5 \mathrm{~m}$ thick), massive to slightly imbricate clast-supported gravel, overlain by horizontally-bedded sand (Table 3; Fig.s 5 and 6). Abandoned channels are filled with interlaminated sand and organic rich silt over thin channel gravel lags. Massive silt and sand cap the entire depositional package. Disseminated plant macrofossils (leaves and twigs) are often present within abandoned channel fills, where-as coarse gravel commonly contains oak logs (Quercus rubra and Quercus robur) near the base of T3 channels. Radiocarbon ages from oak logs and OSL dates from stratified sand constrains the age of $\mathrm{T} 3$ to ca. 4050 to 3200 years BP (Table 2).

\section{Unit T2}

The T2 surface displays a meandering channel morphology that is more sinuous than that of unit T3. The channel floor is not incised below that of T3, and conformable facies are typically less than $4 \mathrm{~m}$ thick (Fig. 4). Channel facies (2-3 m thick) include massive to weakly imbricated gravel, overlain by coarse horizontally bedded sand (Fig. 7). Overbank facies (1-2 m thick) include massive sand and silt, and occasional, interbedded, thin pebbly horizons. T2 overbank sediments locally truncate and/or bury the T3 surface (Fig.s 4 and 5), with constructional surfaces found at elevations up to $5 \mathrm{~m}$ above the modern low water surface. Abandoned channels are filled with discrete sand/silt beds that onlap topographically higher surfaces, and are separated by thin paleosols in channel settings that merge distally into cumulic profiles (Fig. 5). Channel fills generally lack organic material and clay except at the channel base, where logs and sticks are occasionally preserved. Radiocarbon ages from wood in $\mathrm{T} 2$ deposits range from ca 1300 to 1200 years BP.

\section{Unit T1}

$\mathrm{T} 1$ is most readily distinguished by a wide belt of undulating topography that roughly parallels the modern channel (Fig. 6a), reflecting an episode of channel widening and braiding. In positions proximal to the modern channel, streamlined scours and sandy ridges locally erode and/or bury older deposits, where-as in more distal locations, deposition of sand and gravel onto terraces locally obscures older Holocene units, and occasionally preserves paleosols (Fig. 4 and Fig. $6 b$ ). As shown in Table 2, radiocarbon and OSL ages suggest that deposition of $T 1$ occurred ca 680 to 500 years BP.

\section{T0 - Modern depositional environments}

The modern fluvial system most resembles a transitional low sinuosity, meandering/wandering gravel-

Table 3. Facies codes used in figures in this paper (after Miall, 1996).

\begin{tabular}{llll}
\hline Facies code & Facies & Sedimentary structures & Interpretation \\
\hline Fs & Mud, silt & Massive & Overbank deposit; abandoned channel fill \\
Sh & Sand & Horizontal lamination & Upper flow regime planar beds, upper point bar \\
Sm & Sand & Massive & Bioturbated; pedogenically altered \\
Gh & Gravel & Horizontal bedding, clast supported & Channel, lower point bar, diffuse gravel sheets \\
Gm & Gravel & Massive matrix supported & Bedload, debris flow \\
\hline
\end{tabular}



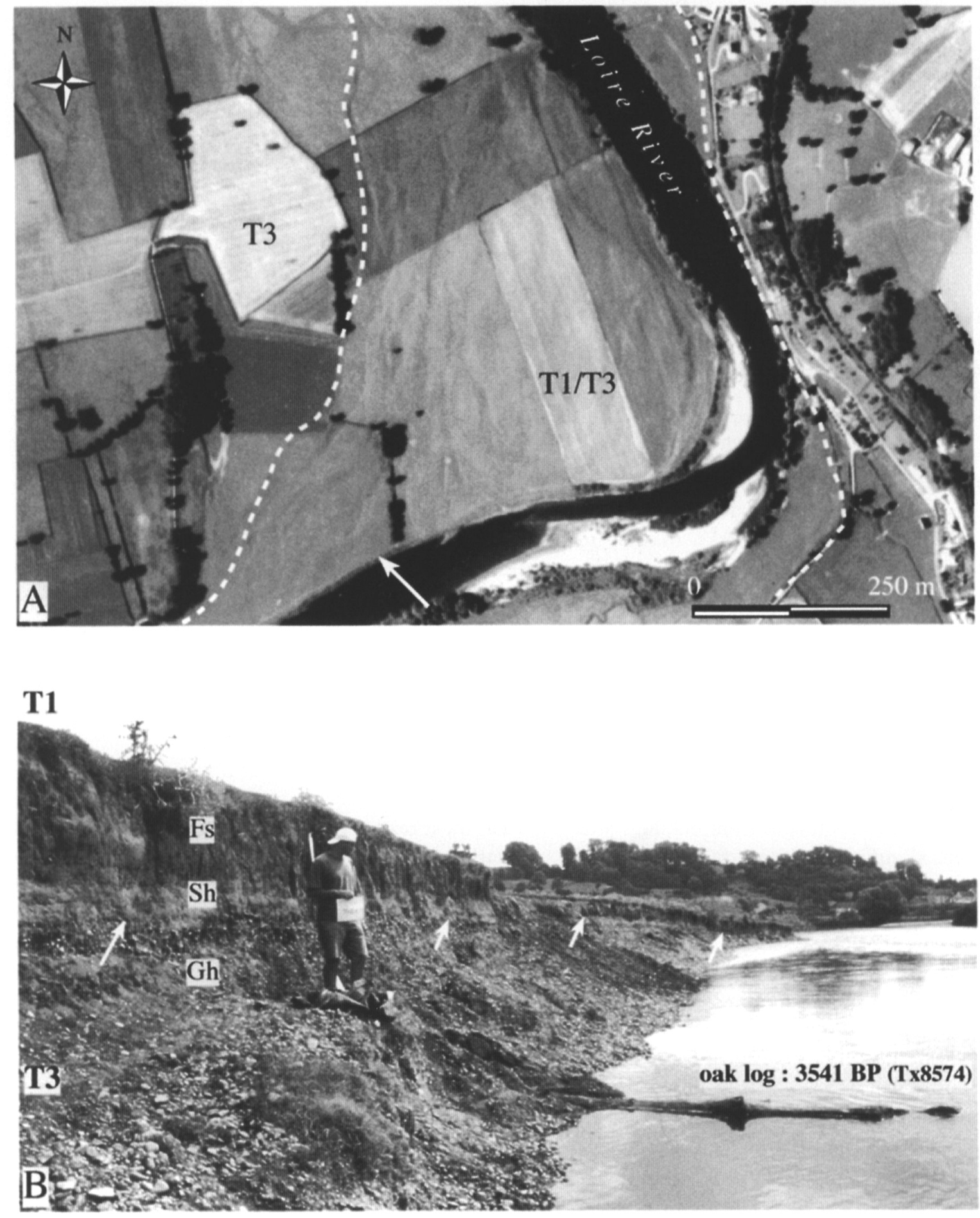

Fig. 6. Aerial photograph of the Loire River showing surface morphology of T1. Arrow points to location of person standing in outcrop photo in $6 \mathrm{~b}$, below. B. View of unit T1 overlying T3 channel facies. Arrows point to erosional base of T1 along length of outcrop. Outcrop location shown by arrow in $6 \mathrm{a}$, above. See Table 3 for facies descriptions.

bed system (Fig. 6a). Channel facies include point and lateral bars composed of clast supported, weakly horizontally-bedded gravel overlain by coarse trough cross-stratified and horizontally bedded sand, and large channel bars composed of massive to slightly imbricate gravels and lesser amounts of planar crossstrata that fill localized scours. Particularly interesting coarse channel-elements associated with this phase of fluvial activity are gravel 'ramps', associated with chutes that cut off meander bends. In these settings, gravel commonly overlies an erosion surface and can be traced in cutbank exposures from the low water channel up through older point bar/overbank facies, scouring into, and on top of, soils as high as $5 \mathrm{~m}$ above the channel. Genetically related floodplain elements include levees comprised of massive sand and 


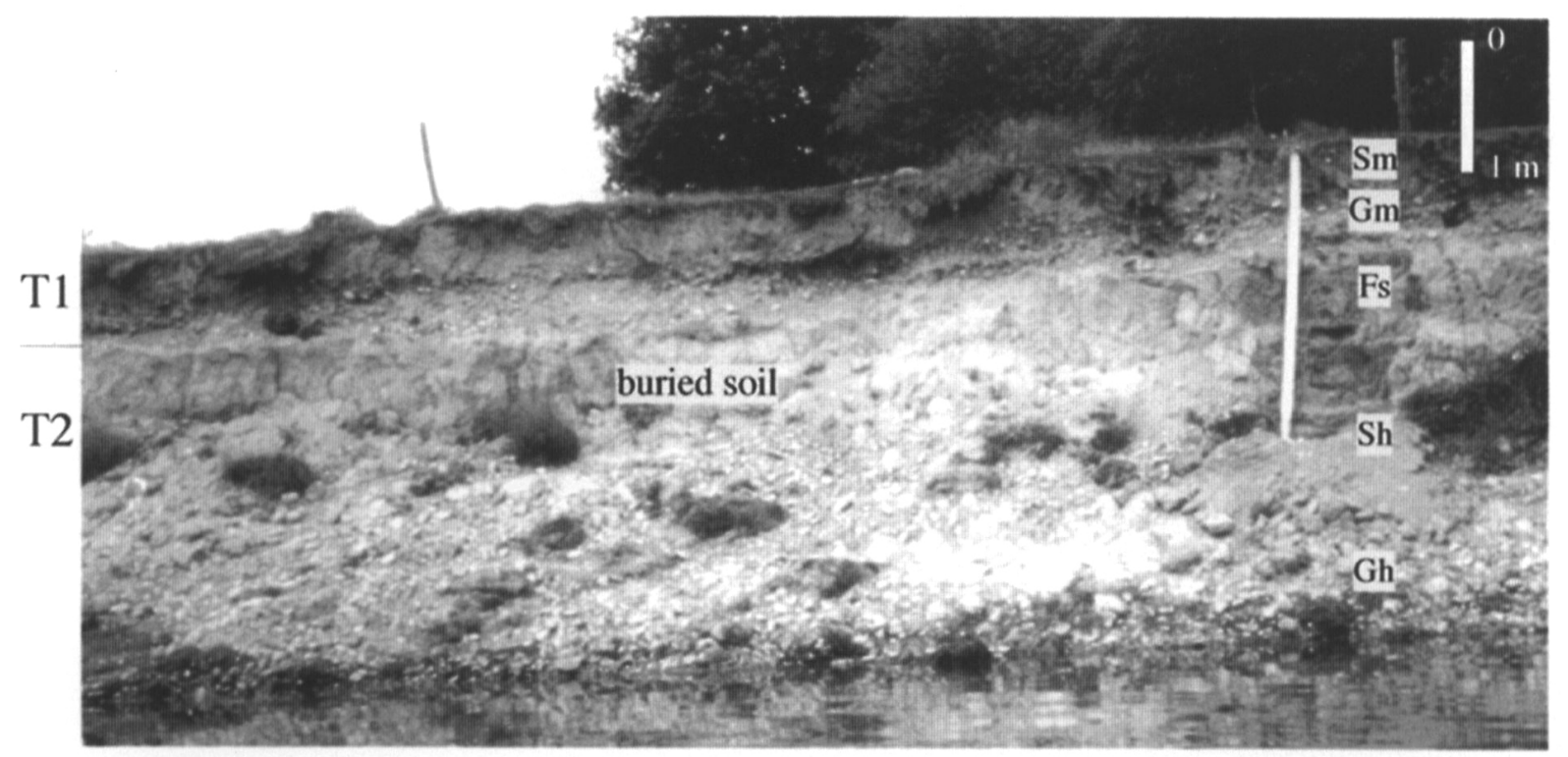

Fig. 7. Outcrop photograph of T1 deposits overlying T2 deposits with moderately well developed soil, in the Arroux valley. See Table 3 for facies descriptions.

silt, distal point bar surfaces that are buried by massive fine sand and silt, and abandoned meander and chute-channels that are filled with laminated sand and silt. Modern fine-grained facies most commonly consist of organic-rich silts that accumulate in slack water environments, where chute-channels re-enter the stream.

\section{Discussion}

Comparison of ice core and marine records with proxy records from the continental interior of western Europe has suggested strong correlations in the timing and magnitude of many climatic episodes (e.g. Bond et al., 1993; Dansgaard et al., 1993; Friedrich et al., 2001; GRIP Project Members, 1993; Stuiver et al., 1995; Tzedakis et al., 2001). Over the Holocene, the comparison of continental and marine records is especially good in terms of the timing (although not necessarily the direction or magnitude) of episodes of climatic extremes, such as the Roman Climatic Optimum, Medieval Warm period, and Little Ice Age, suggesting strong teleconnections between Greenland, the North Atlantic, and regions in Europe (e.g. Barlow et al., 1993; Harrison et al., 1993; Stuiver et al., 1995; Yu \& Harrison, 1995).

While it has been possible to compare the timing of environmental change (as derived from proxy records) with the physical records of fluvial adjustments, it has generally been difficult to quantify relationships between past climate and changes in flood magnitude and frequency (e.g. Knox, 1996). This is due in part to relatively poorly constrained ages for many river systems (Fuller et al., 1998) and the inher- ent difficulty in obtaining detailed cross-sectional dimensions of alluvial channels, but also because there are few long historic records with which to develop models of the relationships between atmospheric conditions and resulting discharge regimes. For the last 4 $\mathrm{ky}$, when boundary conditions were similar to those at present (COHMAP, 1988) the development of such analogue models can begin to overcome generalizations concerning fluvial behavior, by placing a physical climatological context behind observed morphological and sedimentological adjustments. Thus for the late Holocene, the regional proxy record can be considered within the context of a historically defined model of atmospheric variability, so as to more rigorously define hydro-climatological conditions for the study region (e.g. Brown, 1998; Harrison et al., 1993). Changes in sediment yield through time may also be considered, through comparison of the proxy and anthropogenic record with the modern relationships between vegetative cover, land-use, and resulting spatial pattern of sediment yield (e.g. Aubert, 1995). The resulting analogue model of discharge regime and sediment yield for the southern Burgundy region provides a better framework within which to interpret the alluvial stratigraphic record (Fig. 8).

In most cases within the period of historical monitoring, cooler hemispheric temperatures are associated with meridional flow, resulting in the passage of large storms and/or variable to extreme weather conditions over the southern Burgundy region. These conditions are associated with an increased frequency of moderate to large magnitude floods. By contrast, zonal flows occur with warmer hemispheric temperatures and result in relatively dry conditions that pro- 


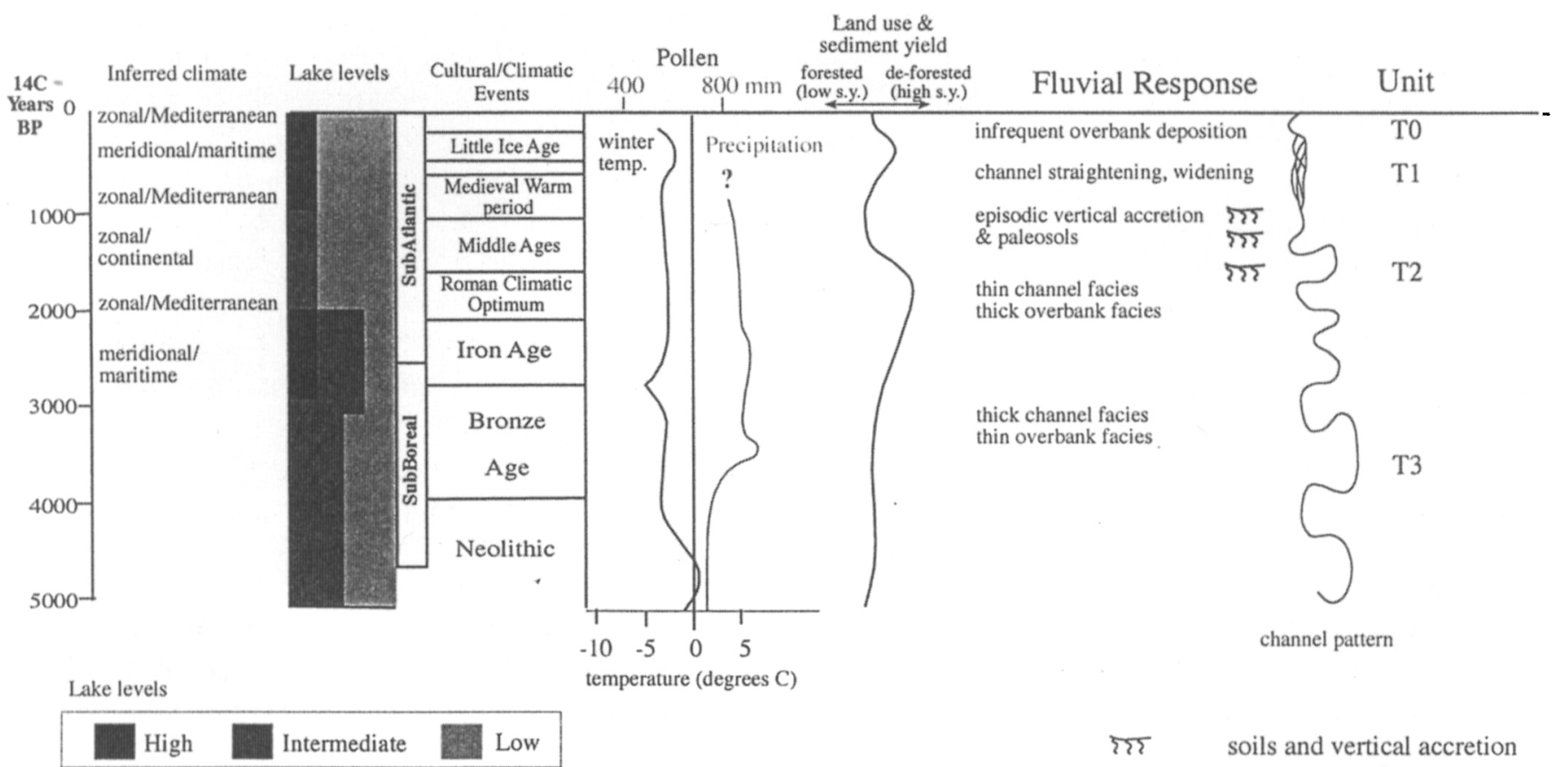

Fig. 8. Comparison of cultural/climatic episodes with moisture and temperature trends developed from pollen records in upper Loire Basin (after Siffendine et al., 1993), lake levels in western Mediterranean region (after Harrison \& Digerfeldt, 1993), landscape/interpreted sediment yield change along valley axes (from archaeological evidence described by Berry, 1987, and Crumley, 1987), and fluvial response of Loire/Arroux trunk/tributary system. The pollen record after $1000 \mathrm{AD}$, is inconclusive due to anthropogenic effects.

duce infrequent, large magnitude floods. These regional controls on hydrologic regime are conditioned by local land-use. For the Loire/Arroux system, increased sediment yields occur with increased cultivation/exposure of the landscape, and with increased discharges and discharge variability.

\section{The SubBoreal $\left(4700-2600{ }^{14} \mathrm{C}\right.$ years $\left.B P\right)$}

In the upper Loire basin, the SubBoreal period was, in general, characterized by cool and moist conditions, forested uplands, minimal hillslope erosion, and high organic sedimentation in upland lakes (Rousseau et al., 1993; Siffendine et al., 1996). Generally high lake levels in the western Mediterranean region also point to moist conditions, and the dominance of a maritime style climate (Harrison \& Digerfeldt, 1993; Yu \& Harrison, 1995), during which time T3 was deposited in the Loire and Arroux valleys.

At a more detailed level, human influence on the landscape in southern Burgundy was probably localized prior to $3 \mathrm{ka}$ (Berry, 1987; Crumley, 1987). Deforestation of uplands and mining activities apparently did not contribute much fine grained sediment from hillslopes, as overbank facies are thin and volumetrically minor. Evidence for a forested valley floor within the study area come from abundant oak trees preserved within gravel channel facies (Fig. 6b), as well as abundant plant macrofossils in abandoned channel fills. Large channel dimensions and thick channel facies, commonly a full meter thicker than in younger deposits, suggest that the depth of relatively frequent, within-channel flows were generally greater than in subsequent alluvial episodes (Fig. 4). Based on the modern analogue model of the Loire system, moist maritime climates during the SubBoreal probably produced relative frequent, moderate to large magnitude discharges, and generally low sediment yields due to the presence of a strong vegetative cover. This episode of intense fluvial activity is coincident with similar active meandering described elsewhere in Europe, including the Rhône/Sâone system ca 4-3 ka (Macé et al., 1991), the Main River in Germany ca 5.6-3.2ka (Becker \& Schirmer, 1977), and the Vistula River in Poland ca 4.5-3 ka (Starkel, 1991a).

\section{The SubAtlantic (2600-0 years BP)}

The early SubAtlantic is generally characterized by dry conditions in the upper Loire basin, which began before human modification of the landscape (Siffendine et al., 1996). Warm, Mediterranean-like conditions during the Roman Climatic Optimum probably resulted from the dominance of strong zonal circulation that displaced storms northward. It is recognized that Mediterranean landscapes generally produce high sediment yields from hillslopes due to sparse vegetative cover (Butzer, 1980; Langbein \& Schumm, 1958), and are often 'sensitive' to environmental perturbation. Deforestation of hillslopes and a major 
shift in the locus of agricultural activity from upland settings to valley bottoms culminated during the Roman Climatic Optimum, and would probably have increased sediment yields at that time (Fig. 8). Through the Middle Ages and into the Medieval Warm period, climatically induced, unstable hillslope conditions may have been exacerbated by changes in land-use between upland and lowland settings through-out the southern Burgundy region (Berry, 1987), thus increasing sediment yields.

At the beginning of the SubAtlantic, T2 deposits record a narrow, highly sinuous meandering stream that became more active and progressively dominated by vertical accretion through time. Thin channel facies and thick overbank facies that contain multiple, weak paleosols, indicate subaerial exposure and persistent low flow conditions. Low lying positions on the floodplain were gradually filled, while higher surfaces were more slowly raised with episodic deposition of silt and the formation of cumulic soils. Maximum elevations of vertical accretion during this phase were, in some locations, equal to the upper surface of T3 (4-5 $\mathrm{m}$ above the low water channel). This suggests that flood peaks (and by inference discharges) increased through the SubAtlantic, and were eventually moderate to large. Based on the modern analogue model, Mediterranean climates probably resulted in generally low-flow conditions, punctuated by infrequent, large magnitude discharges. Sediment yields were likely high, due to the presence of a sparse vegetative cover, increased cultivation of lowlands, and deforestation of uplands. Episodic vertical accretion due to increasing flood magnitudes, as induced by climatic change, has been noted for the Medieval Warm period in both anthropogenically modified and unmodified basins in central Europe (e.g. Kalicki, 1996; Macé et al., 1991). As the Little Ice Age (LIA) approached, climatic conditions became increasingly erratic (Lamb, 1984b), driven by increased meridionality that resulted in large, more frequent discharges.

\section{The Little Ice Age (1350-1800 AD)}

The Little Ice Age characterizes a period of climatic instability in western Europe, that occurred during a well-documented episode of meridional circulation (Moses et al., 1987; Lamb, 1977, 1982). This atmospheric pattern is correlated with the intrusion of large storms into southern Europe (e.g. Hurrell \& Van Loon, 1997; Rogers, 1997), during which time T1 was deposited. There is no evidence for major changes in land use within the Loire/Arroux system that may have significantly altered sediment yields at this time.
T1 is characterized by a distinctive straightened and widened channel pattern with a braided morphology (Fig. 6a). T1 is typically underlain by sandy facies that unconformably overly older channel facies (Fig. 6b), and locally bury previously stable alluvial surfaces as much as $4 \mathrm{~m}$ above the modern channel (Fig. 7). Braiding elsewhere during this period has been related to increased rates of bank erosion, increased sediment contribution from tributary systems and hillslopes, and to increasing flood magnitudes (Rumsby \& Macklin, 1996; Starkel, 1991a). Many other European rivers experienced significant morphologic change during the Little Ice Age. The lower Loire, for example, changed from a meandering to braided planform, interpreted to be the result of decreased bank stabilizing vegetation (Bomer, 1972). The Garonne also experienced frequent, large floods during the Little Ice Age (Decamps \& Fortune, 1991).

\section{The Modern system}

Following the LIA, the upper Loire and Arroux were transformed into the transitional meandering/wandering pattern seen today. The lower Loire and Garonne Rivers were also transformed from wide, shallow and unvegetated braided streams, to narrower island-braided patterns in lower reaches (Bomer, 1972; Decamps \& Fortune, 1991). The most recent changes in channel morphology may be related to changes in discharge regime associated with increasingly zonal circulation and the dominance of a more Mediterranean style climate that produced infrequent, large discharge events. Frequent within-channel flows result in minimal deposition of channel bars and in low-lying back-water channels. Evidence for infrequent, very large floods come from gravels that were transported up and onto terrace surfaces as much as $5 \mathrm{~m}$ above the low water channel, a phenomena limited to post-LIA meander cut-offs.

\section{Conclusions}

The Loire and Arroux Rivers, a trunk/tributary system, have responded to environmental change with similar morphological and sedimentological adjustments through time (Straffin et al., 1999). Several lines of evidence point to climatic change and resulting differences in discharge regime as a primary control on depositional style, with patterns of land-use and vegetative cover playing a secondary role by controlling the quantity of sediment available for overbank deposition.

First, the relationships between atmospheric flow 
and the spatial distribution and style of storms across western Europe have been documented and quantified (e.g. Hurrell, 1995; Hurrell \& Van Loon, 1997). Discharges also vary in spatially distinct patterns, even between river systems with grossly different geologic conditions and drainage basin morphologies (Fig. 2; Gustard et al., Probst, 1987; Probst \& Tardy, 1989). It seems likely that atmospheric circulation is responsible for the observed similarities in these historically recorded discharges, and not changes in land-use and river-taming activities. These same relationships most likely apply throughout the last $4 \mathrm{ky}$, when atmospheric boundary conditions were similar to those at present (COHMAP, 1988).

Secondly, the regional similarity in the response (both erosional/depositional episodes, as well as morphology and facies architecture) of these rivers strongly suggests that an allocyclic process (climate) has been the dominant mechanism driving these fluvial adjustments (e.g. Antoine, 1994, 1997; Blum et al., 1994; Vandenberghe, 1995). The response of large alluvial systems such as the Loire should also be less affected by localized and internal complex-response mechanisms (e.g. Blum et al., 1994). If land-use were a primary control conditioning fluvial dynamics, one might expect to find differences in response between the larger trunk stream (Loire) and much smaller tributary (Arroux), as changes in land-use between the basins have not been exactly the same, or of the same magnitude, through time. Instead, fluvial dynamics have been very similar in both valleys.

Further support for climate as the driving mechanism behind regionally similar alluvial sequences is the fact that morphology and facies architecture is consistent with that expected during climatic episodes, as defined by independent paleoenvironmental records. For example, proxy records suggest a predominantly Mediterranean style climate during the Roman Climatic Optimum through the Medieval Warm period. One would expect to find geologic evidence of dry conditions punctuated by infrequent, large magnitude (overbank) events, characteristic of this style of climate. Floodplains dominated by vertical accretion of overbank sediments that are separated by thin paleosols is evidence for this style of activity, and is characteristic of the Loire/Arroux system at that time. Similarly, the style of deposition of all units correlate well with the discharge regimes expected during climatic episodes defined by the proxy record during the late-middle Holocene. Based on these relationships, it seems that the question of human influence as a driving mechanism in the development of regional scale fluvial successions seems unlikely, although humans have likely had a secondary impact, by conditioning the quantity of sediment available for overbank deposition.

\section{Acknowledgements}

Funding for research was generously provided through a Doctoral Dissertation Improvement grant (award \# SBR-9506643) from the National Science Foundation, Geography and Regional Science Program, and grants from the Geological Society of America. Thanks also to reviewers Philip Gibbard and Andy Howard for valuable suggestions that helped to improve the manuscript.

\section{References}

Antoine, P., 1994. The Somme Valley terrace system (northern France): A model of river response to Quaternary climatic variations since 800,000 BP. Terra-Nova 6: 453-464.

Antoine, P., 1997. Modification des systèmes fluviatiles à la transition Pléniglaciaire-Tardiglaciare et à l'Holocene: L'example du bassin de la Somme (Nord de la France). Géographie Physique et Quaternaire 51(1): 93-106.

Aubert, D., 1995. Analyse des fluctuation interannuelles des débits et des transports fluviaux de sédiments sur les fleuves et rivières de Bourgogne. Analyse de données hydro-climatologiques et géochimiques, modélisation. Unpublished Projet de Recherche de Maîtrise, Universite Louis Pasteur, CNRS (Strassbourg): 25 pp.

Barlow, L.K., White, J.W.C., Barry, R.G., Rogers, J.C. \& Grootes, P.M., 1993. The North Atlantic oscillation signature in Deuterium and Deuterium excess signals in the Greenland ice sheet project 2 ice cores, 1840-1970. Geophysical Research Letters 20 (24): 2901-2904.

Becker, B. \& Schirmer, W., 1977. Palaeoecological study on the Holocene valley development of the River Main, southern Germany. Boreas 6: 303-321.

Benito, G., Machado, M.J. \& Perez-Gonzalez, A., 1996. Climate change and flood sensitivity in Spain. In: Branson, J., Brown, A.G. \& Gregory, K.J. (eds.): Global Continental Changes: the Context of Palaeohydrology. Geological Society Special Publication 115: 85-98.

Berry, W., 1987. Southern Burgundy in Late Antiquity and the Middle Ages. In: Crumley, C.L. \& Marquardt, W.H. (eds.): Regional Dynamics: Burgundian Landscapes in Historical Perspective. Academic Press (San Diego): 447-607.

Birkeland, P.W., 1984, 1999. Soils and Geomorphology. Oxford University Press (New York) $2^{\text {nd }} \mathrm{Ed}, 3^{\text {rd }} \mathrm{Ed}$.

Blanchet, G., 1990. Regimes meteorologiques et diversité climatique dans l'espace Rhônalpin. Revue de Géographie de Lyon 65(2): 106-117.

Blum, M.D., Toomey, R.S. \& Valastro Jr., S., 1994. Fluvial response to Late Quaternary climatic and environmental change, Edwards Plateau, Texas. Palaeogeography, Palaeoclimatology, Palaeoecology 108: 1-21.

Blum, M.D. \& Straffin, E.C., 2001. Fluvial responses to external forcing: Examples from the French Massif Central, the Texas coastal plain, the Sahara of Tunisia, and the lower Mississippi Valley. In: Maddy, D. \& Macklin, M.A. (eds.): River Basin Sediment Systems: Archives of Environmental Change. Balkema Press (Lisse): 195-228.

Blum, M. D. \& Tornqvist, T. E., 2000. Fluvial response to climate 
and sea-level change: a review and look forward. Sedimentology 47 (Supplement 1): 1-48.

Bomer, B., 1972. Les îsles de la Loire: évolution ou stabilité. Etudes Ligeriennes: 69-80.

Bond, G., Broecker, W., Johnsen, S., McManus, J., Labeyrie, L., Jouzel, J. \& Bonani, G., 1993. Correlations between climate records from North Atlantic sediments and Greenland ice. Nature 365: 143-147.

Bond, G.C. \& Lotti, R., 1995. Iceberg discharges into the North Atlantic on millennial time scales during the last glaciation. Science 267: 1005-1010.

Brackenridge, G.R., 1988. River flood regime and floodplain stratigraphy. In: Baker, V.R., Kockel, R.C. \& Patton, P.C. (eds.): Flood Geomorphology. John Wiley and Sons (New York): 139-165.

Bravard, J-P., 1992. Rapport No. 2: Les rythemes d'évolution morphologique des vallées Françaises au Tardiglaciaire et l'Holocène. Bulletin de Association Géographique Française (Paris): 207-226

Bridgland, D.R., 2000. River terrace systems in north-west Europe: an archive of environmental change, uplift and early human occupation. Quaternary Science Reviews 19: 1293-1303.

Brown, A.G., 1998. Fluvial evidence of the medieval warm period and the late Medieval climatic deterioration in Europe. In: Benito, G., Baker, V.R. \& Gregory, K.J. (eds.): Palaeohydrology and Environmental Change. Wiley (Chichester): 43-52.

Bull, W. B., 1991. Geomorphic responses to climate change. Oxford University Press (London).

Butzer, K.W., 1980. Holocene alluvial sequences: Problems of dating and correlation. In: Cullingford, R.A., Davidson, D.A. \& Lewin, J. (eds.): Timescales in Geomorphology. John Wiley and Sons (London): 131-142.

COHMAP Project Members, 1988. Climatic changes of the last 18,000 years: Observations and model simulations. Science 241: 1043-1052.

Colls, A., 1999. Optical dating of fluvial sediments from the Loire Valley, France. Unpublished MS thesis, University of Oxford: $85 \mathrm{pp}$.

Colls, A., Stokes, S., Blum, M.D. \& Straffin, E., 2001. Age limits on late Quaternary evolution of the upper Loire River. Quaternary Science Reviews 20: 743-750.

Crumley, C., 1993. Analyzing historic ecotonal shifts. Ecological Applications 3(3): 377-384

Crumley, C.L., 1987. Historical Ecology. In: Crumley, C.L. \& Marquardt, W.H. (eds.): Regional Dynamics: Burgundian Landscapes in Historical Perspective. Academic Press (San Diego): 237-264

Crumley, C.L. \& Marquardt, W.H., 1987 (eds.). Regional Dynamics: Burgundian Landscapes in Historical Perspective. Academic Press (San Diego).

Dai, A., Fung, I.Y. \& Del Genio, A.D., 1997. Surface observed global land precipitation variations during 1900-88. Journal of Climate 10: 2943-2961.

Dansgaard, W., Johnsen, S.J., Clausen, H.B., Dahl-Jensen, D., Gundestrup, N.S., Hammer, C.U., Hvidberg, C.S., Steffensen, J.P. Sveinbjornsdottir, A.E., Jouzel, J. \& Bond, G., 1993. Evidence for general instability of past climate from a 250 -kyr icecore record. Nature 364: 218-220.

Decamps, H, \& Fortune, M., 1991. Long term ecological research and fluvial landscapes. In: Long Term Ecological Research: 137151 .

Deleage, A., 1941. La vie rurale en Bourgogne jusqu'au début du onzième siècle. Protat Freres (Mâcon).

DIREN, 1996. Direction Regionalé de L'Environnement: Bassin de Loire-Bretagne.

Fager, K-D. \& Lozek, V., 1982. Climatic change, archaeology and
Quaternary science in the eastern Mediterranean region. In: Harding, A.F. (ed.): Climatic Change in Later Prehistory. Edinburgh University Press: 143-161.

Fauquette, S., Guiot, J., Menut, M., De Beaulieu, J.-L., Reille, M. \& Guenet, P., 1999. Vegetation and climate since the last interglacial in the Vienne area (France). Global and Planetary Change 20: 1-17.

Friedrich, M., Kromer, B., Kaiser, K., Spurk, M., Hughen, K. \& Johnsen, S., 2001. High resolution climate signals in the BøllingAllerød Interstadial(Greenland Interstadial 1) as reflected in European tree-ring chronologies compared to marine varves and ice-core records. Quaternary Science Reviews 20: 1223-1232.

Fuller, I.C., Macklin, M.G., Lewin, J., Passmore, D.G. \& Wintle, A.G., 1998. River response to high-frequency climate oscillations in southern Europe over the past 200 k.y. Geology 26: 275278.

Goossens, Chr., 1985. Principal component analysis of Mediterranean rainfall. Journal of Climatology 5: 379-388.

GRIP Greenland Ice-core Project Members, 1993. Climate instability during the last interglacial period recorded in the GRIP ice core. Nature 364: 203-207.

Guillet, B., Janssen, C.R., Kalis, A.J. \& De Valik, E.-J., 1976. La végétation pendant le Post-Glaciaire dans l'est de France. In: Guilaine, J. (ed.): La préhistoire française, v.2, CNRS: 82-94.

Gunn, J. \& Crumley, C. L., 1991. Global energy balance and regional hydrology: A Burgundian case study. Earth Surface Processes and Landforms 16: 579-592.

Gustard, A., Roald, L.A., Demuth, S., Lumadjent, H.S. \& Gross, R., 1989. Flow Regimes from Experimental and Network Data (FREND) Volume 1 Hydrological Studies, UNESCO International Hydrological Programme: 344 pp.

Hargrove, T., 1994. Rapport sur la Prospection et les Fouilles, Commune d'Uxeau. Direction Regional de l'Archeologie de Bourgogne (DRAC), Dijon.

Harman, J.R., 1991. Synoptic Climatology of the Westerlies: Process and Patterns. The Association of American Geographers: $80 \mathrm{pp}$

Harrison, S.P. \& Digerfeldt, G., 1993. European lakes as palaeohydrologic and palaeoclimatic indicators. Quaternary Science Reviews 12: 233-248.

Harrison, S.P., Prentice, I.C. \& Guiot, J., 1993. Climatic controls on Holocene lake-level changes in Europe. Climate Dynamics 8: 189-200.

Hurrell, J., 1995. Decadal trends in the North Atlantic Oscillation: regional temperatures and precipitation. Science 269: 676-679.

Hurrell, J. \& Van Loon, H., 1997. Decadal variations in climate associated with the North Atlantic Oscillation. Climatic Change 36: 301-326

Jones, E., 1994. Rapport sur la Prospection et les Fouilles, Commune d'Uxeau. Direction Regional de l'Archeologie de Bourgogne (DRAC), Dijon.

Kalicki, T., 1996. Climatic or anthropogenic alluviation in Central European valleys during the Holocene? In: Branson, J., Brown, A.G. \& Gregory, K.J. (eds.): Global Continental Changes: the Context of Palaeohydrology. Geological Society Special Publication 115: 205-215.

Knox, J.C., 1975. Valley alluviation in southwestern Wisconsin. Annals of the Association of American Geographers 62: 401-410.

Knox, J.C., 1983. Responses of river systems to Holocene climates. In: Wright, H.E. \& Porter, S.C. (eds.): Late Quaternary environments of the United States: The Holocene. University of Minnesota Press (Minneapolis): 26-41.

Knox, J.C., 1996. Fluvial systems since 20,000 yrs BP. In: Gregory, K. J., Starkel, L. \& Baker, V. R. (eds.): Global Continental Palaeohydrology. John Wiley and Sons (Chichester): 87-108. 
Kozarski, S., Gonera, P. \& Antczak, B., 1988. Valley floor development and paleohydrologic changes: Late Vistulian and Holocene history of the Warta River (Poland). In: Lang, G. \& Schlüchter C. (eds.): 'Lake, Mire and River Environments' Balkema (Rotterdam): 185-204.

Langbein, W.B. \& Schumm, S.A., 1958. Yield of sediment in relation to mean annual precipitation. Trans. Am. Geophys. Union 39: 1076-1084.

Lamb, H.F., 1977. Climate: present, past and future. Methuen (London): 835 pp.

Lamb, H.F., 1982. Climate, History, and the Modern World. Methuen (London).

Lamb, H.F., 1984a. Climate in the last thousand years: Natural climatic fluctuations and change. In: Flohn, H. \& Fantechi, R. (eds.): The Climate of Europe: Past, Present and Future. Reidel (Holland): 25-64.

Lamb, H.F., 1984b. Some studies of the Little Ice Age of recent centuries and its great storms. In: Morner, N.A. \& Karlen, W. (eds.): Climatic Changes on a yearly to Millenial Basis. Reidel (Holland): 309-329.

Leroux, M., 1990. Les conditions dynamiques moyennes du climat de la France. Revue de Géographie de Lyon 65 (2): 63-79.

Macé, S., Vérot-Bourreloy, A. \& Bravard, J.P., 1991. Genèses et fonctionnement Holocène de la Plaine alluvialle du Rhône a Lyon. $116 \mathrm{e}$ Cong. Nat. des Soc. Sav., Chambéry, Préprotohistoire: 17-31.

Macklin, M.A. \& Lewin, J., 1996. Holocene river alluviation in Britain. Z. Geomorph. Supp. 88: 109-122.

Miall, A.D., 1996 The geology of fluvial deposits. Sedimentary facies, basin analysis, and petroleum geology. Springer (New York) $582 \mathrm{pp}$.

Moses, T., Kiladis, G.N., Diaz, H.F. \& Barry, R.G., 1987. Characteristics and frequency of reversals in mean sea level pressure in the north Atlantic sector and their relationship to long-term temperature trends. Journal of Climatology 7: 13-30.

Ohmori, H., 1983. Erosion rates and their relation to vegetation from the viewpoint of world-wide distribution. Bulletin of the Dept. of Geogr., University of Tokyo 15: 77-91.

Pandzic, K. \& Trninic, D., 1992. Principal component analysis of a river basin discharge and precipitation anomaly fields associated with the global circulation. Journal of Hydrology 132: 343-360.

Probst, J-L., 1989. Hydroclimatic fluctuations of some European Rivers since 1800. In: Petts, G. E. (ed.): Historical Changes of Large Alluvial Rivers, Western Europe. John Wiley and Sons (New York): 41-55.

Probst, J.-L. \& Tardy, Y., 1987. Long range stream flow and world continental runoff fluctuations since the beginning of this century. Journal of Hydrology 94: 289-311.

Reille, M. \& De Beaullieu, J-L., 1988. History of the Wurm and Holocene vegetation in western Velay (Massif Central, France). A comparison of pollen analysis from three corings at $\mathrm{Lac} \mathrm{du}$ Bouchet. Review of Palaeobotany and Palynology 54: 233-248.

Rodwell, M.J., Rowell, D.P. \& Folland, C.K., 1999. Oceanic forcing of the wintertime North Atlantic Oscillation and European climate. Nature 398: 320-323.

Rogers, J.C., 1997. North Atlantic storm track variability and its association to the north Atlantic Oscillation and climate variability of northern Europe. American Meteorological Society 10: $1635-1647$.

Rousseau, D-D., Limondin, N. \& Puissegur, J-L., 1993. Holocene environmental signals from mollusk assemblages in Burgundy, France. Quaternary Research 40: 237-253.
Rumsby, B.T. \& Macklin, M.G., 1996. River response to the last neoglacial in northern, western, and central Europe. In: Branson, J., Brown, A.G. \& Gregory, K.J. (eds.): Global Continental Changes: The Context of Palaeohydrology. Geological Society Special Publication 115: 217-233.

Schirmer, W., 1988. Holocene valley development on the Upper Rhine and Main. In: Lang, G. \& Schlüchter, C. (eds.): Lake, Mire and River Environments. Balkema (Rotterdam): 153-160.

Schumm, S. A. \& Brackenridge, G. R., 1987. River Responses. In: Ruddiman, W. F. \& Wright, H. E. (eds.): North America and Adjacent Oceans During the Last Deglaciation. Geological Society of America, Decade of North American Geology K-3: 221-240.

Siffendine, A., Bertrand P., Lallier-Vergès, E. \& Patience, A.J., 1996. Lacustrine organic fluxes and palaeoclimatic variation during the last $15 \mathrm{ka}$ : Lac Du Bouchet (Massif Central, France). Quaternary Science Reviews 15: 203-211.

Starkel, L., 1987. Anthropologic sedimentological changes in Central Europe, In: Starkel, L. (ed.): Anthropogenic sedimentological changes during the Holocene. Striae 26: 21-29.

Starkel, L., 1991a. The Vistula River valley: A case study for Central Europe. In: Starkel, L., Gregory, K. J. \& Thornes, J. B. (eds.): Temperate Palaeohydrology. John Wiley and Sons (Chichester): 171-188.

Starkel, L., 1991b. Long-distance correlation of fluvial events in the temperate zone. In: Starkel, L., Gregory, K. J. \& Thornes, J. B. (eds.): Temperate Palaeohydrology. John Wiley and Sons (Chichester): 473-495.

Staron, G., 1990. La spécificite pluviometrique du Massif Central - Revue de Géographie de Lyon 65(2): 90-96.

Staron, G., 1993. Chronologie des catastrophes pluvieuses dans le sud de la France. Revue de Géographie de Lyon 68: 91-100.

Straffin, E.C., 2000. Fluvial response to climate change and human activities, Burgundy, France. Unpublished Ph.D. dissertation, University of Nebraska-Lincoln.

Straffin, E.C., Blum, M.D., Colls, A. \& Stokes, S., 1999. Alluvial Stratigraphy of the Loire and Arroux Rivers, Burgundy, France. Quaternaire $10(4): 271-282$.

Stuiver, M., Grootes, P.M. \& Braziunas, T.F., 1995. The GISP d 180 climate record of the past 16,500 years and the role of the sun, ocean and volcanoes. Quaternary Research 44: 341-354.

Stuiver, M., Reimer, P.J., Bard, E., Beck, J.W., Burr, G.S., Hughen, K.A., Kromer, B., McCormac, F.G., Van der Plicht, J. \& Spurk, M., 1998. Radiocarbon 40: 1041-1083.

Tabony, R., 1981. A principal component and spectral analysis of European rainfall. Journal of Climatology 1: 282-294.

Taylor, M.P. \& Lewin, J., 1997. Non-synchronous response of adjacent floodplain systems to Holocene environmental change. Geomorphology 18: 251-264.

Tzedakis, P.C., Andrieu,V., De Beaulieu, J.-L., Crowhurst, S., Follieri, M., Hooghiemstra, H., Magri, D., Reille, M., Sadori, L., Shackleton, N.J. \& Wijmstra, T.A., 1997. Comparison of terrestrial and marine records of changing climate of the last 500,000 years. Earth and Planetary Science Letters 150: $171-176$.

UNESCO, 1979. Discharge of selected rivers of the world.

Vandenberghe, J., 1995. Timescales, climate and river development. Quaternary Science Reviews 14: 631-638.

Vines, R.G., 1985. European rainfall patterns. Journal of Climatology 5: 607-616.

Yu, G. \& Harrison, S.P., 1995. Holocene changes in atmospheric circulation patterns as shown by lake status changes in northern Europe. Boreas 24: 260-268. 